Stankiewicz W., Institutional determinants - decorations or yoke - a crisis test, „Ekonomia i Prawo. Economics and Law”, Polszakiewicz B., Boehlke J. (ed.), Vol. 14, No. 3/2015, pp. 369-387. DOI: http://dx.doi.org/10.12775/EiP.2015.024.

\title{
INSTITUTIONAL DETERMINANTS DECORATIONS OR YOKE — A CRISIS TEST
}

\author{
SUMMARY
}

Institutional determinants of economic crises as a subject of scientific study is a compromise between quality notions and quantity calculation. Under pressure of practical governing and disrupted by crises, economic thought developed some concepts and doctrines, addressed to the state authorities. As attractive component theory of economic cycles come out institutionalism. The concepts of two scholars: Svetlana Kirdina (Russia) and Thráinn Eggertson (Iceland) are worth noting. S. Kirdina promote the theory of an institutional matrix, where the area of conflicts is located. Eggertson is recognized as an author of the theory of imperfect institutions and limit of reform.

Interesting issues, both theoretic and practical ones, against the background of Ukrainian drama, may be found in publications of Vladimir Lipov. He developed methodology of institutional economics and focused attention on the theory of goods, especially on dual notions complementary and substitution. As a starting point to an analysis, Lipov proposes the structure of institutional blocs. Progressing gradually and employing the dynamics of blocs cooperation, he justifies the importance of complementary. It provides an opportunity to analyze an institution from a structural and functional angle.

"Wacław Stankiewicz, Warsaw Private School of Business, Public Administration and Information Technology, ul. Bobrowiecka 9, 00-728 Warszawa, Poland, phone: +48 2255920 00, e-mail: waclawstankiewicz@poczta.onet.pl. 
In the further section of the paper, Hyman P. Minsky's "financial instability hypothesis" is extensively covered and discussed. Among the reasons, the rebirth of Keynesianism and the pressure exerted by the last American crises are listed. Financial instability is blamed very intensively. Given the above, various determinants are obviously necessary but always distant from a perfect resolution.

Keywords: economic crises; institutional economics; imperfect institutions; financial instability hypothesis

JEL Classification: B52; B310

\section{INTRODUCTION}

There was time in my life when I discovered and used with a fairly good effect the advantages of command, as a decision widely used among soldiers and well known in military practice. The pattern of this concept is clear, simple sentence structure - who has to do it and by what means. I would add, it is based on the belief that we can quantify quality and issue accurate assessment. It is not difficult to recall that history long ago puts forward a serious reservations and imposed the present unpleasantness of experiencing uncertainty, complexity of situation and limitations in activities of social communities. The attractiveness of the position of a commander, especially for a person boasting ferocity instinct and joy of coercion expressed towards subordinates, underwent a process of weakening due to the need to adapt compromise and the advantages of management in conducting operations removed far from the military battlefield. Fate granted me the opportunity to modestly comment on the effectiveness of various actions and very numerous concepts, from which I learned and passed the knowledge to others, risking also the conflict of conscience.

For the purposes of this paper and by courtesy of PT organizers of the conference, and thus not in response to command and without a critical assessment of my views, I suggest the following plan for the paper to achieve its objectives, which I hope will not exceed the allocated time while being presented.

In accordance with an overview of the available information, both scientific and on popular science and adopting a subjective approach to the issues discussed out of the sheer curiosity instinct ( pure or futile, or simply "idle curiosity"), I would like to Focusing attention on the significance of "the institutional determinants of the phenomenon of crises, which is of vital importance not only in the sphere of institutional economics, I would like to tackle three points: 
1. Key words, which impose discipline on to speakers and certain boundaries of analysis in the field of interaction of so many doctrines of modern science.

2. The specifics of research fields, particularly in the institutional matrix and and in the spheres causing conflicts and crises.

3. Test dynamics (ordeal) and scientists resistance.

\section{A FEW CHALLENGES AND PROPOSALS FOR USE}

An obvious need to choose the words considered key to the reader is not simple, because it forces to auto-da-fé or a striptease. It is easy to see when participating in a discussion on "institutions" perceived as ordinary economic entities or terms necessary to give a lecture on institutional economy. In my lecture I tried out the usefulness of the following definition: "economic institution is a set of rules that shape cooperation in economic processes, especially in the broadly understood exchange" ${ }^{1}$. The specificity of this speech, especially the need for displaying the less known concepts constitutes a challenge which I have to meet.

Let me begin by recalling a few proposals for the integrated approach combining the cyclical nature of the phenomenon of economic crises with the theory of institutionalism, which promotes the significance of the idea of "institutional conditions of crisis"2. Despite the fact that we may encounter other definitions of those concepts, we may boldly apply them in the situations when "some object depends on conditions". At present, the institutional component, shaping the economic cycle is of vital importance due to the expansion of the financial sector. The hierarchy of the institutional system of society, puts the idealistic institutions (axiological values) way above the political, legal and economic ones.

The dynamics of ideological institutions allows to further examine the research field, which constitutes a potential minefield. The initial state is a hierarchical complementarity, the relations of inclusion/subordination, isomorphism and congruence, and thus universal compatibility. However, we need

${ }^{1}$ W. Stankiewicz, Ekonomika instytucjonalna. Zarys wyktadu, Wydawnictwo AON, Warszawa 2014 , p. 52.

${ }^{2}$ I used clear reasoning from a chapter by Lipov V.V., Институциональная обусловленность экономических ичиклов: проблема комплементарности институтов, [in:] К.А. Хубиев (еd.), Мировой экономический кризис и тенденции развития российской экономики, MGU, Moscow 2010, pp. 53-60. 
to break away and dream, which we call for, at least for a momentary pleasure. The longing for beautifully dressed utopia never disappears. Obviously, we need it in spite of bitter experiences recorded in the history of cycles and crises. The confrontation of subsidiarity doctrine with quite widely propagated doctrines of matrices $\mathrm{X}$ and $\mathrm{Y}$ constitutes a good preparation for a bitter lesson. Below are a few theses of a widely known Russian scholar Swietlana Kirdina ${ }^{3}$.

First of and foremost, she did a lot in order to restart a discussion of the Soviet political economy and the defense system that exists in the Russian Federation. In my opinion, an attractive concept of socio-economic matrices enables to determine the similarities and differences between Western $(\mathrm{X})$ and Eastern Europe (Y) institutional matrix, leaving a place for an indepth discussion among axiologists and even utopians, which is slightly connected with the ideology of subsidiarity. At this level it does not harm anyone to proclaim the principle of individualism, the priority rights of the individual over the rights of the community. Differences of opinion become clear during the analysis of base institutional matrices, when the history of the development of capitalism and the history of the experiment of real socialism are still familiar to many scientists. Here are brief signals in this matter.

In the very beginning it is noted that the western matrix and its susbsidiarity are deeply rooted in religious values, especially Protestantism. In contrast, the evaluation of eastern axiological matrix is based on communitarism, and therefore it draws from older traditional religions. At this level, very little may be said about the institutional conditions which in the world history brought extremely durable crises. Russian science and practice with characteristics far away from successes and a clear pressure on the exposition of history of the Czarist economy "razdatocznoj", do not encourage the adoption of such standards. Even if the arguments in favor of the difference between East and West matrices are worthy of discussion in science, it is much more difficult to share without emotions the criticism of presentation of the institutional matrix of the Russian Federation.

Discernible axiological foundations of the economic system at lower levels of management are more frequently logically and ideologically supported than find scientific background. The juxtaposition of such institutions in matrices of the Russian economy and "western", which often include: ownership, work relations, entrepreneurship, the flow of economic goods, criteria for success, money, finances and the tools of control of the economic mechanism, still resemble the period of socialism development in the Soviet Union. It's hard

${ }^{3}$ S.G. Kirdina, X- и Ү-экономики: институциональный анализ, Nauka, Moskwa 2004. 
to preach another cry for real "institutional conditionality" yet another utopia or an experiment of rational banditry.

Let a concise presentation of the concepts of one of the leading economists and world renowned scholars, who being a leader in global science, is a loyal follower of the state, which has never been a superpower, bring some relief. The person, I would like to focus attention on is obviously an Icelander who has not been awarded a Nobel Prize yet. Here is Thráinn Eggertson (b. 1941), whom I have never met, but I was lucky to visit Iceland and get there a handful of quantum of joy. I can strongly recommend Eggerton's publications. I just would like to mention a massive work by the above mentioned author titled Economic behavior and institutions which was published in 1990 and highly valued by the main centers of modern science. New institutional economics was supported by the young behavioral economics, and veblenists and discussants engrossed in the methodology helpful in the analysis of law and economy links, received new ideas to penetrate a conflict-inducing matrix. Now, however, it is time to share insights from reading a monograph titled Imperfect Institutions. Possibilities and Limits of Reform ${ }^{4}$.

The author explicitly called a comprehensive introduction to the monograph Missed opportunities? He assumes that most nations did not take advantage of the technological revolution. Moreover, he clearly points that it is due to social institutions imperfections that generate poverty and backwardness. Three parts of the works form a concise whole, but probably it is the first part, the theory of imperfect institutions which plays a difficult role of an intellectual provocation. Easier in reception and discussion is the second part, where empiria presents a case study, namely the trap of poverty and the threat of famine in Iceland. Similarly, the third part, which deals with institutional policy does not chase for originality, but aspires to be more effective in practice due to the institutional conditioning, without an excessive fear of surprises typical of an economic cycle.

According to Eggertson, the theory of imperfect institutions emerges from the theory of economic growth, which overly focused on physical dependencies of inputs/results and less on the environment itself which guarantees growth. Hence, a simplification, poor countries because they lack capital and technology itself is not to be blamed. Eggertson writes on the theory of growth and dawdlers falling into trouble: "It seems that the theorists of the new theory prefer to deal with approximated or direct variables of growth instead of base

${ }^{4}$ T. Eggertson, Imperfect Institutions. Possibilities and Limit of Reform, University of Michigan Press, Ann Arbor 2005. 


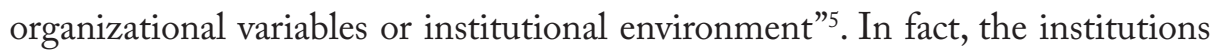
and social technologies constitute barriers to growth. Eggertson highly values the attempts to build a multidisciplinary theories. He claims that social and physical theories are complementary and admits that social technologies are tougher to implement than the physical ones. New social technologies are even a critical barrier to growth in poor countries.

Eggertson saves his reader and only mentions key aspects of the institutional doctrine, which is essential for simple discussions rather than a demonstration of unpopular ideas. He is often in favour of a role of master North's in creating economic science and maintaining the distance in polemics. However, he strongly emphasizes the significance of technology in society. He enhances the methodology by presenting the category of imperfect institutions and subjecting to discussion a historical phenomenon, the long-term history of stable poverty and unstable economic growth. Well known examples of shocks came from the exchange (trade) and from nature itself, which disrupted the consistency and sustainability of social and political systems. Scientific correctness of expression regarding eg. a point growth can not hide the drama of entire areas of a socio-economic matrix.

According to Eggertson, the theory of imperfect institutions finds the right style in the known discussion on the formation of state institutions, inspired by a legendary bandit and his transformation in the behavior towards primitive communities. Instead of a drastic change of a journeying raider, a nice story about understanding the quantitative relations of input and results through coercion works well to facilitate the upbringing of successive generations. A real treat is organized for us and a colorful exchange of views on The political logics of bad economics. So, let us talk in the state of biological satiety, the aura of safety and a growing prosperity in which a politician, the operations of authorities chosen thanks to selectors, is assessed by dull scholars as bad economy. Possibly we have already forgotten about the rich heritage of theater and the art of role reversal, joy and sorrow of actors and the audience, and finally about the inevitable moment when we have to leave the party.

Eggertson proposes a good lecture in this field. It bears a somewhat perverse title The standards against standards in economy. As we know, the standards were included in the first theses of institutional economics and were established in the attempts to understand information as a phenomenon of rarity and transaction costs. Social norms emerged spontaneously and for

\footnotetext{
${ }^{5}$ Ibidem, p. 21.

${ }^{6}$ Ibidem, pp. 75-78.
} 
academic science had long been a hindrance in creating rules of management . It is worth remembering that the mainstream economic thought was determined to disregard religious standards and sought rather "standards against standards". Eggertson writes that norms are deeply embedded in the structure of social system. I would add that this approach may also be found in the concepts of institutional matrix of S. Kirdina and it fits well into a set of inefficient standards of social norms and a more general concept of imperfect institutions.

If we accept such image with a relief, we also accept the view of Demsetz (1967) on a tendency to treat the new standards as very useful for the process of internalization. Concerns about the institutional conditioning of politics and economy requires constant vigilance also towards operations of a benevolent Samaritan, not to mention the ambitions of dictators and great leaders. Eggertson writes: "It does not matter which side we support in a discussion, but it is clear that the economic result depends on the prevailing mixture of standards, statutes, regulations, and the ruling courts. It is also not clear that the social forces will always dictate a mix of institutions providing maximum prosperity. (...) The evaluation of the effectiveness of social technology should not focus on the individual rules or norms and their effectiveness, but on the whole cluster containing different combinations of formal and informal institutions"?.

Let me now remind you a painful and scientifically valuable case study, which we were kindly supplied by Eggertson in the chapter titled Why Iceland starving? It is a rare case of the use of such a transparent object of study of a socio-economic system in the macro scale. From $13^{\text {th }}$ to $19^{\text {th }}$ century, Iceland was the area of economic and institutional matrix, which benefitted from undeveloped production and social technology. It is peripheral Europe, separated by the seas, with the population of approximately 50 thousand people, farming agriculture, herding and farming, using only a modest amount of wonderful fish from the rich resources of the sea. Overseas contacts without long-lasting economic and political connections. Until $13^{\text {th }}$ century, state authority was based on the tribal leaders, later it was exercised by the governors of the King of Norway or Denmark. The system was close to autarky, equilibrium imposed by own customs and law. Historians discuss the paradox of the implementation of the agrarian strategy in the form of institutions of the right to collect stocks of feed (hay) and the principles of selfhelp. The conflicts of interests between landlords and farmers, which prevailed for so long, must have had their share in the trap of hunger.

\footnotetext{
${ }^{7}$ Ibidem, p. 82.
} 
The first lasting contacts with maritime commerce and the expansion of the Hanseatic League, English and obviously Danish, forced the adaptation of new technologies and social institutions. It was a huge shock when the Icelanders discovered a real access to marine resources. Starting with the dramatic purchasing of cutters in Norwegian shipyards, hiring farmers and herders to fish in far away waters and, finally, developing an enthusiastic adoption of social technologies. Significant increase in population, urbanization and industrialization, and after World War II, independence and respect from the contemporary world.

A lecture on institutional policy included in the book, also covers the issues of determinants favourable for the operations in a business cycle. Eggertson relies on the old theory of economic policy, but focuses on the role of social technologies. Therefore, he wrote: "The purpose of the normative theory of institutional policy is to develop strategy for repairing the dysfunctional institutional environment. This, after all, fundamentally different institutional policy, shares the overall vision of the macroeconomic policy and planning" lem involved in taking such a decision is a collection of four components: 1) policy model, 2) a set of tools of this policy; 3) an objective function and 4) methods of calculating the value for policy measures, which maximize the objective function.

In this context, the introduction of private policy models, the elements of social engineering and creative behaviors promoted by the theory of rational expectations, is also indispensable. Personally, I perceive such a gesture as a concession in the name of consent. The author of the book obviously wrote on the basic lesson, which is understanding that the results of public policies depend not only on the political government models, but also on private models of policy and acting of individual actors in social theater.

The attitude of the renown Icelander allows to eliminate the excessive attempts to defeat the critics and keep an appropriate distance, also from the proposal of institutional determinants protecting us against crises. Obviously, the offer of the optimal socio-economic governance is still intangible, elusive and quite close to daydreaming. Thus, I will quote Eggertson opinion in this respect. He argues his right to deal with "imperfect institutions", offering their definition of "in the aura of comparative institutional analysis. According to this definition, institutions may be imperfect, both exogenously and endogenously. The set of institutions is exogenously imperfect (or ineffective) in the eyes of the observer, who believes that an alternative set of in-

\footnotetext{
${ }^{8}$ Ibidem, p. 127.
} 
stitutions could provide a higher effect than that specified by the criterion used by him".

I am finishing to praise Eggertson and sharing his conclusion, or rather an appeal to support the subtle art of directional institutional reform, although he himself will probably not give up the direct participation in the support of magnificent Iceland.

\section{IN THE PURSUIT OF COMPLEMENTARITY}

Vladimir Valentynowicz Lipov has already been presented in the first chapter, but now, when I wish to discuss in more detail his interesting concept of complementarity as a tool for the analysis of socio-economic systems, I do not have enough information on this outstanding Ukrainian scholar. As a professor of Kharkiv National University of Economics, he is the author of publications on international economics and the science of management. Moreover, in my opinion, he is also a creative specialist in the methodology, institutional economics and an author who is worth exploring as a representative of the group of scientists who are so close to the conflict and drama of Ukraine. In an atmosphere of intellectual unrest, but also an acute crisis and the so-called. hybrid war, I have selected a number of topics of "civilian" nature, wandering seekers of political transformation using achievements of institutionalism and my personal appeal for the need to support our Polish science of defense economy.

Obviously, considerations on the determinants and institutional complementarity, should remain in close relation, though, with sufficient recognition of the specific nature of both concepts ${ }^{10}$.

An allegation against economists that they can not prove the inverse of the two terms in the theory of goods, which is complementarity and substitution, should be considered tactless. The necessity of complementarity of goods and the possibility of their replacement, in the process of grad-

\section{Ibidem, p. 141.}

${ }^{10}$ From a selection of numerous publications by V.V. Lipov, Институциональная комплементарность в формировании и развитии национальных сочиально-экономических систем стран мира, „Terra Economicus” Vol. 4/2009, pp. 51-67; V.V. Lipov, Институциональная комплементарность как фактор формирования сочиально-экономических систем, "Journal of Institutional Studies", Vol. 4, No. 1/2012, pp. 25-42; V.V. Lipov, Комплементарность институциональных блоков как инструмент анализа социально-экономических систем, „Економіка розвитку”, Vol. 3, No. 67/2013; V.V. Lipov, Институциональная гетерогенизаичия и гибкая интегращия, „Научные труды ДонНТУ”, Vol. 1/2014, pp. 128-138. 
ing creative activities, is what we served all life long. According to W. Lipov, complementarity of such good as the socio-economic system, plays an important role in the creation, formation, operation and development of global and national political systems. The author stresses that his studies are to serve Ukraine. When examining the correctness of institutional cooperation within the framework of defined blocks and then their dynamics within the broad framework of a political system, he attempts to detect and prove complementary conditioning of components of such institutional blocks. I think, such restrictions are worth respecting, when even beautifully designed tectonics of the socio-economic system is offered to practice capable of action closer than we can observe today.

In a nutshell, I am offering a description of Lipow cncept, and more of a brief summary, without full responsibility for probable simplifications and omissions. First step is a presentation of the institutional ladder of architectonics of the socio-economic development. The hierarchy of the analyzed elements can easily be found on the levels whose number allows for the reduction and replenishment. Additionally, they enable to satisfy curiosity as for similarities with analyses of other sciences. Lipov considered 5 levels to be sufficient, and therefore compatible in many facets sociologists and some methodologists views. Everyone has the right to number the stages in a lecture and call them: nano, micro, meso, macro and mega. However, it is much more difficult to justify "cast" of those stages. I confess that I still find it problematic to function in the nano, meso and mega spheres. I can better understand technologists and cosmologists understand, but why the lowest level of the architectural hierarchy are occupied by the needs, values, individual knowledge, routine and collective behavior? All of that could generate a lengthy discussion...

The concept of institutional complementarity of socio-economic systems also allows Lipow to treat the two components of institutional relations, structural and functional, as maintaining their individual character, relatively independent, but complementary to each other in the reproduction process of the system. Therefore, two aspects of complementarity, structural and functional, may be subject to analysis. Thus, the above mentioned purpose of study has to be specified, and so the complementary conditions of institutionaltional blocks explored and evaluated for durability of institutional communities and forms of cooperation existing in the given fields of functional social reproduction. The identification of institutional blocks as objects of research, requires one to opt for one of the sets offered by the theory of regulation and the concept of capitalism diversity. For the purpose of our meeting, 
just a short enumeration of the following blocks and mechanisms of complementarity will suffice.

There is a block of finance system that mediates in the flow of household savings into the realm of production, carrying out the functions of accumulation, concentration, control the allocation and the control of efficient use of financial resources. It is worth remembering that the relation individualism/collectivism, which is the basis of structural complementarity, manifests itself differently, as a dichotomy in decision-making where there is an entity and the financial system resources. The priority given to individualism or collectivism prejudges the rules of the game in this block. We have an access to numerous versions of analyzing and designing of the system and drama boils down to the interference from the military and political sides.

Sufficiently tested corporate governance still attracts with the mirage of high efficiency of corporate resources use, if they create numbers of small businesses owners of capital. Professional management is the domain of managers and no one can clearly and fairly agree with certain groups of interests. The inherited methods of real socialism were pushed to the margin of scientific inquiry, numerous and bold concepts of capitalism emerged, which are public, mezzo-corporate, north and central European concepts. The orientation in the abundance of legal standards of the contemporary corporatism requires a huge effort of the experts in law and economics.

The production relations block, where the dream constructive partnership is deformed by the forces of the conflicting interests of employers and employees still constitutes a mother lode of contradictions. The state has to frequently maneuver between the parties in the labor markets, in the conditions of dichotomy of the pay systems which are centrally regulated and deregulated decentrally.

Further institutional blocks are subjected to the challenges of complementarity, emerging from the dynamic system of the labor force, entrepreneurship and the state. Such block having a strong impact on the economic cycle is a system of educating and training personnel, in which the interests of the groups are manifested with persistence typical of technical and scientific revolution. We can spare the general aspect of these issues presented by Lipov, since in Poland, it is the area analyzed carefully, and even well received in economic circles. The same is true with respect to the block of business manufacturing models, which are just in their infancy on the way to become widespread. It is about creating local and regional communities, connections between small businesses and, at the same time, taking advantage of habits and best practices for community operations. In order to preserve traditions, the development cultural initiatives and the protection of patrimony, 
such activities deserve being taken notice of. Moreover, we should also bear in mind the discussions and practical achievements of the movement of creating a welfare state to spread optimism reaching even the limits of satire. However, the block called national innovation system cannot be disregarded. The above mentioned system probably found in Poland not only almost enthusiastic reception, but also reasonable translation of the value of the phenomenon of progress into quantitative indicators of progress.

Professor Vladimir Lipov serves Ukraine and also science firmly based on the methodology of institutionalism well. A transparent analysis of the institutionalblocks conducted by Lipov for the good of his country proves the advantages of complementarity lecture within the architectonics of socio-economic systems. Along with developing the theory, Lipov participates in substantive discussions dealing with progress of the political transformation of Ukraine; also in the assessment of the impact impact of operations serving complementarity. I would like to draw attention to another of his articles, in which he points out the successful attempts to take into account the specifics of the Ukrainian socio-economic system ${ }^{11}$.

In Lipov's work, the general recognition of the transformation system boils down to the challenges which generated attempts similar to those known in our country, namely, an immediate return to market capitalism. The energetic political power often broke the practice of socialist planning and the scientific analysis of particular institutional units began to discover an explicit oversight of the phenomenon of diffusion of the processes of improving their institutional complementarity.

I would like to highlight the fact that at the school we received information on a spontaneous equalization of concentration as a result of random thermal motion of matter particles, which invariably leads to mixing of various gases, liquids and solids. There is a number of attractive publications of the spontaneous birth of the origins and the invisible hand, but almost immediately, it seems that a feeling of insufficiency is born along with a temptation to interfere, especially to demolish structures. At times, it is also a source of detrimental effects, originally extremely attractive activities involving succumbing to such values which are offered by individualism and collectivism corporativism. According to Lipov, the political transformation of Ukraine in the 90s shattered the existing structural and functional base of institutional complementarity. Additionally, it destroyed priceless value of the folk tradition and some partial or sectoral successes.

11 V.V. Lipov, Структурная комплементарность институциональных блоков в Украине: диффузия вместо трансформащии, „Економіка розвитку”, Vol. 4, No. 68/2013. 
Inaccurate or hesitant opening of Ukraine to one of two possible scenarios turned out to bring painful consequences for the process of financial complementarity. The first one focused on the fact that their existing economic potential allowed to choose the system while still retaining the great advantages of highly varied, complex, but at the same time a significant entity of the global economy. The second scenario was grounded in high specialization in the field of production for export. Lipov suggests a compromise scenario. According to him, the developing economy sectors which provide a synergy effect of increased profit from economies of scale should constitute the basis of Ukraine transformation success. It should be supported and fostered by the new and prevailing technologies acting as a catalyst to implement models of socio-economic locomotives. The dynamics of innovation processes, along with the transformation of agrarian and neoindustrial complexes, is necessary. Finally, the author makes a summary simply proposing replacing the priority of setting traditional secular-rational values with a socially oriented priority of self-actualization in the sphere of survival and consent values.

I will finish by mentioning V. Lipov publication containing reflections on the enormous diversity of the European Union institutional system, which must raise concerns before Ukraine joins the historical process of integration on the continental level. After all, the EU benefits from the wealth, or perhaps, struggles with its excess, in the form four main capitalism systems and the diversity of its members. The attempts to analyze such structures in Asia and on a global level, induce genuine headaches not only in case of scholars. Lipov himself suggests handling such heterogenization in the institutional space extremely carefully. Notably, he refers to adopting the institutions of alternative models, which incidentally violates the traditions and cultural layers. Although Europe has a serious historical experience and in the current stage of integration is doing quite well with the matrix of institutional barriers, there are constant conflicts between the states of such a small region on a global scale ${ }^{12}$. Flexible integration is recommended as a universal remedy, despite the awareness that this concept is also difficult in practice.

In difficult situations, we often resort to humor, risking that our own opinion will be subject to community assessment. There are known jokes about the pleasure of the very act of "catching a bunny" rather than turning it into a roast. In the current drama, numerous speakers voice their opinions and it has to be kindly noted that they are looking for solutions wor-

12 S.S. Hrynkevych et al., Усовершенствование институционального регулирования системы сочиальной безопасности Украины, „Современные проблемы науки и образования", No. 6/2012. 
thy of respect, knowing the Latin saying that Inter arma silent musae. Let me, therefore, resort to the publication of a group of scholars from Lviv Academy of Commerce, who place the support of Ukraine social security system ${ }^{13}$ among the current and strategic tasks.

First of all, the authors write about the crisis of the whole social system, which translates into a crisis of nation and state. The issue of regionalisms has become exacerbated and requires improvements of Ukraine whole social doctrine. Its main principles have to be implemented. These include: optimal combining of liberalism with the control of state power, radicalization of work motivation, emphasizing a great importance of the family institution, activating local governments and initiatives to resolve grave regional conflicts, creating effective programs of social action, sustaining the fight against discrimination against women and surrounding the ethnic and religious communities with assistance. A great system of institutional adjustment should operate under conditions conducive to the complementarity of three subsystems: information, decision-making and motivation systems. We wish them good luck!

\section{FINANCIAL SENSITIVITY HYPOTHESIS}

The reference to the content of the concept which is widely discussed in the contemporary economic thought, can be justified in a little perverse way. On the one hand, there are numerous publications binding the hypothesis of financial sensitivity with critical assessment of the current economic crisis, which is given an almost global dimension, and on the other hand, a surprising confession of Hyman P. Minsky (1919-1996), who was the author of the hypothesis, that he perceives his contribution as a modest enrichment Keynesian tradition. As a presenter of my view on the role of institutional determinants necessary for existence in the face of the economic crisis, I have decided to announce a few observations.

Let me start semi-jokingly and, drawing from Latin Nibil Novi, recognize the contribution of the biblical patriarch Joseph into the treasury of the theory of the business cycle ${ }^{14}$. Joseph took advantage of an extremely simple and therefore socially comprehensible model for describing the process of creating danger and policies to prepare for crisis challenges. Its structure encompasses a macro scale, the whole system of ancient Egypt, the process of con-

\footnotetext{
13 Ibidem.

${ }^{14}$ I would recommend a skillfully prepared text from Millennium Bible, Geneis, chapter titled The Exaltation of Joseph, Pallotinum Publishing House, Poznań 1971.
} 
trol exerted by the state, i.e. a wise and absolute Pharaoh, the main production processes and economic exchanges so strongly influenced by the Nile activity cycle and practical power contact based on a drastic coercion of science reaching the heights of theory cultivated also by eminent practitioners. Thus, it was a model understandable for authority and accepted by the population, already familiar with of a series of floods of the Nile, and having experienced crop failures and famine. It is the acceptance of $7+7$ years cycle and an offer for scientists ambitious to explore the theory of such a high standard, or like us, the seekers of institutional determinants of crisis. Let me recall a small bit of history of the economic thought ${ }^{15}$.

Literature on the subject encompasses a set of issues which may be presented in the form of monographic considerations on selected crises, or a wider picture of the economic cycle theory and the examples of inspiration of assessing the contribution of scholars not only from the economics and social sciences. In my view, the presentation by Mrs Wioletta Nawrot is very apt. Although she adopted the model of Minsky's financial crisis, she also pointed to his links with the cycle theory and the history of crises, focusing the final analysis on the phenomenon of financial instability (or sensitivity). Observation of natural, economic and social phenomena, generated an abundant research material and numerous doctrines also to be used in practice. Thick volumes of history and an avalanche of information on the Internet are doomed to the risk of incorrect selection of examples. Valuable ones, as for the significance of the impact of a particular object of the research is, among others, 19-month Kitchin inventory cycle, 7-8- year investment cycle in the construction of Juglar production plants, 20-year cycles in Kuznets housing and the revived concept of Kondratieff long waves development. It has to be noted that the research objects were usually big and blurred and therefore far removed from the needs of precise presentation. Minsky studied the history of economic thought for a long time and participated in ambitious discussions, which created a general framework for his own view of the financial crises and the original model representing a modern approach to this phenomenon.

The key concept of the lecture is "instability" and the related "sensitivity" as a feature of any financial system. According to Minsky, in the mainstream

15 I relied on very good sources: W. Nawrot, Teoria kryzysów finansowych Minsky ego $i$ jej odniesienie do wspótczesności, „Gospodarka Narodowa”, Vol. 10/2009, pp. 49-69.; R. Pollin, The Relevance of Hyman Minsky, „Challenge”, Vol. 40, No. 2/1997, p. 75-94 . For the tired: K. Marczak, K. Piech, Cykle koniunkturalne: ujęcie bistoryczne i przegląd gtównych teorii, http:// www.academia.edu (15.01.2015). 
of the economic thought, no great importance of interference and rank was attributed to the conflicts in the functioning of banking and market economy. Only the scale of the "Great Depression" and the shock with the size of state intervention in the structure and financial law, forced deep changes in current doctrines. The problematic situation in the $70 \mathrm{~s}-80$ s of the last century became more complicated, less stable and more crisis-inducing. The following factors are listed among the reasons. First, profound changes in the approach to finances of such economic entities as households and businesses, becoming dependent on the financial market. Secondly, there was a significant increase in dependence in short-term liabilities section, in practice carried out at the expense of long-term liabilities. Such reason, known from tradition, but on a smaller scale, also occurred in case of repaying debts contracted from new commitments. The plague of the proliferation of "exotic" financial instruments, which was increasingly exceeding the boundaries of law, also came as a surprise. Minsky himself ventured to assume that a growing tendency to risk in the very financial institutions, was a significant cause of instability.

I came to a stage in this paper, where I have to express my standpoint on the issue I dubbed "minefield" in the title. While asking for understanding, I would like to use this concept adopted from the resources of the military thought to consider the still discussed crisis model presented by Minsky, as another attempt to deal with situations of uncertainty and still unreliable risk calculation ... The atmosphere of tension between the sin of quantification of the phenomenon inherent in quality still prevails. The attempts at clear assignment of Minsky to Post-Keynesian economics or, simply, a group of mathematical economics aficionadoes, will still appear ${ }^{16}$. Personally, I appreciate Minsky's modesty and courage. He prefers to be an eclectic rather than scholars dictator. For the purposes of this paper, I use a fairly traditional and popular description of a model of such object as a financial crisis which is a component of the economic crisis.

Let the starting point be borrowed from psychology and behavioral economics of a relationship between the behavior of borrowers and lenders, and therefore the parties of the minefield which is tempting and masked by traps. In the analysis, initial and subsequent reconnaissance of the situation, usually bilateral increase in optimism occurs. We bear in mind that it was a situation to talk about the joys of balance and development within a specific socio-economic system. Such situation is said to be stable. The threat comes secretly, we do not value the prophets, and obviously the first step on a minefield does

${ }^{16}$ I. Bludnik, Postkeynesizm. Teoria endogenicznej kreacji pieniadza, Wydawnictwo UE w Poznaniu, Poznań 2015. 
not have to be connected with the death of a daredevil. The situation is gently changing for the borrowers mesmerized by the forecasts of the increasing investments profitability, and, surprisingly, lulls bankers vigilance against the risk of lending to increasingly weaker investors. We begin to encroach on the field more clearly marked as "mines", and in the theory of the business cycle masters of economics as "prosperity". We must recognize the master Minsky was a miser and emotionally cold in naming the subsequent steps of the threat escalation.

Again, it is worth asking psychologists and sociologists about an accurate analog of the degrees of escalating madness of some individuals and groups in the researched object. There is a rising tendency of borrowers to borrow at different rates for the processes of consumption, investment and speculation. Scientific-technical revolution sparked an avalanche of information, in which, in fact, we can rely more on luck than on quantifiable indicator. Mathematisation of economics and the temptation to put the blame on the machines and accountability of the decision-makers also in such an institution like the state, does not have to lead to paradise. The progress in the size and structure of consumption is true, but basically, it is difficult to defend the rational choice and control of consumer demand of the cosnumers. This lack of perfection is transferred to a tendency to invest, when the tastes and preferences defy the rules inherited for centuries and the so-called common sense. My parents did not take out bank loans to buy cars or build a shopping center. Additionally, there is a questionable promotion of the Latin concept of speculation, which instead of a lofty activity of recogniion, meditation and study, is at the service of extremely greedy borrowers. It is speculation, which constitutes an impetus for the situation leading from the state of euphoria to madness. Now the "minefield" becomes a matter of certainty in the business cycle and receives the title of "bubble" not to frighten people with a sapper saying "leaps up on a mine".

\section{CONCLUSIONS}

In the title, as well as in the introduction, I was cautious not to carelessly into discussion of a clearly critical or original nature. Although in the first sentence, the question arose whether "ornaments or yoke?", in the conclusion the answer will be rather evasive. Presenting tightly selected material from professional literature which is perhaps too difficult for, I bear in mind a few rules. First and foremost, not to drown in the streams of data, which lead to a problematic situation. To put it differently, I am aware of clash- 
es between scholars and practitioners in the atmosphere of uncertainty and pressure exerted by decision makers in a particular socio-economic system. Secondly, not to usurp the talent to express a definite assessment "ornaments or yoke", for a fairly simple reason that a recourse to language close to profanum is not considered to be proper in the temple of institutional economics. Thus, I am in favour of a compromise assessment and while observing the object named "Institutional determinants", I tried to draw from a concept encouraging a joyful contact with science. So let us continue to take advantage of "institutional determinants", even if a problematic situation contains an element of coercion or lack of variously called joy. And thirdly, by nature I remain very sensitive towards "determinants" related to a specific location of a given phenomenon cycle. It came as no surprise to be engrossed in monographs on specific or implied crises, although I grieve deeply if it affects me directly.

\section{BIBLIOGRAPHY}

Bludnik I., Postkeynesizm. Teoria endogenicznej kreacji pieniadza, Wydawnictwo UE w Poznaniu, Poznań 2015.

Eggertson T., Imperfect Institutions. Possibilities and Limit of Reform, University of Michigan Press, Ann Arbor 2005.

Hrynkevych S.S., Ilyash O.I., Halkiv L.I., Усовериенствование институиионального регулирования системы социальной безопасности Украины, „Современные проблемы науки и образования", №. 6/2012.

Kirdina S.G., $X-$ и Ү-экономики: институциональный анализ, Nauka, Moskwa 2004.

Lipov V.V., Институциональная гетерогенизация и гибкая интеграция, „Научные труды ДонНТУ", Vol. 1/2014.

Lipov V.V., Институциональная комплементарность в формировании и развитии начиональных сочиально-экономических систем стран мира, „Terra Economicus" Vol. 4/2009.

Lipov V.V., Институциональная комплементарность как фактор формирования социально-экономических систем, "Journal of Institutional Studies", Vol. 4, No. $1 / 2012$.

Lipov V.V., Институциональная обусловленность экономических ииклов: проблема комплементарности институтов, [in:] К.А. Хубиев (ed.), Мировой экономический кризис и тенденции развития российской экономики, MGU, Moscow 2010.

Lipov V.V., Комплементарность институциональных блоков как инструмент анализа сочиально-экономических систем, „Економіка розвитку”, Vol. 3, No. 67/2013. 
Lipov V.V., Структурная комплементарность институциональных блоков в Украине: диффузия вместо трансформации, „Економіка розвитку”, Vol. 4, No. 68/2013.

Marczak K., Piech K., Cykle koniunkturalne: ujęcie historyczne i przegląd gtórwnych teorii, http://www.academia.edu (15.01.2015).

Millennium Bible, Pallotinum Publishing House, Poznań 1971.

Nawrot W., Teoria kryzysów finansowych Minsky'ego i jej odniesienie do wspótczesności, „Gospodarka Narodowa”, Vol. 10/2009.

Pollin R., The Relevance of Hyman Minsky, „Challenge”, Vol. 40, No. 2/1997, http:// dx.doi.org/10.1080/05775132.1997.11471964.

Stankiewicz W., Ekonomika instytucjonalna. Zarys wyktadu, Wydawnictwo AON, Warszawa 2014. 
